Acta Agroph., 2019, 26(4), 23-30

doi: $10.31545 /$ aagr/118013

\title{
DEVELOPMENT OF ORGANIC FARMING IN POLAND \\ OVER THE PERIOD OF 2004-2018
}

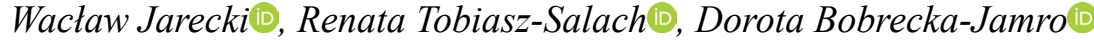 \\ Department of Plant Production, Faculty of Biology and Agriculture, University of Rzeszów \\ ul. Zelwerowicza 4, 35-601 Rzeszów, Poland \\ e-mail: waclaw.jarecki@wp.pl
}

\begin{abstract}
The objective of the study was the analysis of changes in the development of organic farming in Poland over the period of 2004-2018. The results obtained indicate that following the accession of Poland to the EU organic farming in the country developed dynamically. However, since 2014 the situation has changed and a decrease in the number of organic farms has been noted for the first time. The area of arable soils during the conversion period decreased over the years 2012-2015. As a result of that, the area of arable lands in organic farms with certificates began to shrink since 2015 . Within the period under analysis a change of area structure of organic farms took place. Hence, in the years 2016-2018 a high percentage was constituted by farms with areas of 10-20 ha and 20-50 ha, the share of small and very small farms being also significant. The Polish production of organic produce is diversified regionally, which is well illustrated by the latest data from the individual provinces. In terms of the total number of organic farms, the Warmińsko-mazurskie and Podlaskie Provinces are outstanding. The largest total area of lands under organic farming is to be found in the Warmińskomazurskie and Zachodniopomorskie (West Pomeranian) Provinces.

Keyw ords: organic farming, number of farms, area of agricultural lands, area structure
\end{abstract}

\section{INTRODUCTION}

The dynamic development of organic farming in Poland resulted from the introduction of subsidies for this type of agricultural activity. Equally important was also the growing consumer awareness concerning the quality of food products and the improving level of income of the population (Nowogródzka 2012, Domagalska and Buczkowska 2015, Barłowska et al. 2017). Ligenzowska (2014) reports that the highest number of consumers prepared to pay a higher price for organic food products dominates in the United States and in the European Union. Biernat-Jarka and Trębska (2018) noted that since 2014 the number of organic farms in Poland began to decrease, which resulted from numerous causes. Brodzińska $(2010,2014)$ 
believes that the decrease is primarily due to changes in the system of support for organic farming, reducing the financial benefits for certain organic farmers. Jończyk (2014) observes, on the other hand, that a revision of the rules of support for organic farming was necessary, and in a further perspective should be oriented towards support for farms that implement the best the principles of sustainable development. According to Marszałek (2018), the supreme principle of the idea of sustainable development is the maintenance of balance between three systems: economic, social and ecological. Crowder and Reganold (2015) and Brzezina et al. (2017) report that, apart from direct subsidies, factors of the development of organic farming should include various forms of incentives for converting farms to environment-friendly production. Hole et al. (2005), as well as Głodowska and Gałązka (2017), take note of the environmental benefits of the development of organic farming and its positive effect on the quality of soil, water, air, or landscape. Jasiński et al. (2014) conclude that organic farming should rank high in agricultural policy due to the trend towards ecological development. Staniak (2014) and Kowalska (2015) are of the opinion that organic food should be available on the market inn greater amounts. Hence the importance of investment in the processing and distribution of organic food products and bringing the values of organic food to the awareness of the population.

The objective of the study was to present the changes in the development of organic farming in Poland over the period of 2004-2018.

\section{MATERIAL AND METHOD}

The status of organic farming in Poland is reported for the period of 2004-2018. Selected data from the Provinces are presented for the years 2017-2018. Source data for the elaboration of the results were acquired from the Reports of the Inspection of Commercial Quality of Agricultural and Food Products (IJHARS). Our own calculations were made using the Microsoft Excel. The compiled data were used to determine the trend line of organic farms and organic areas in the agricultural lands structure and the trend equation was calculated. The values of the coefficient of determination $\mathrm{R}^{2}$ are also presented.

\section{RESULTS AND DISCUSSION}

The number of organic farms in Poland increased dynamically until 2013. In subsequent years, however, it began to decrease, which was noted for the first time in 2014 (Fig. 1). In spite of that, in the analysed period the trend of the number of organic farms remained increasing. Nevertheless, if the decrease of the number of organic farms continues, that situation may change. 
According to Kisiel and Grabowska (2014), the strongest impact on the increasing number of organic farms was that of the realization of the environmental management scheme, and within its scope - organic farming subsidies. The possibility of obtaining such financial support was the primary determinant of the conversion of farms to the organic system of agricultural production. Drabarczyk and WrzesińskaKowal (2015) believe that the lower subsidies projected for the period of 2014-2020 and the change of the rules of granting the subsidies caused that the number of organic farms began to shrink. This indicates that some of the farmers did not have any long-term intention operating their farms following the organic methods.

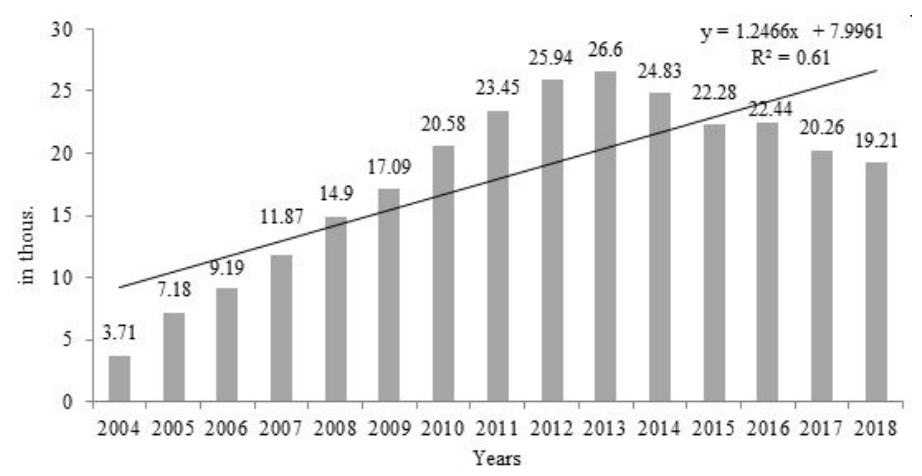

Fig. 1. Number of organic farms in Poland (Source: IJHARS).

In the years 2004-2014 the area of organic farmlands increased gradually after the end of the conversion period. This finds support in the plotted trend line (Fig. 2). Note should be taken, however, that starting from 2015 the situation changed. As a result of that, in 2018 the area of organic farmlands after the end of the conversion period decreased by 192.3 thousand hectares compared to the year 2014 . Kondratowicz-Pozorska (2014) believes that this an effect of changes in system of subsidies for organic farming that were introduced from 2014. It became apparent that the functioning of the Polish organic farms was too strongly dependent on EU and Polish funding, and on the agricultural policy. Krupa et al. (2016) confirm that in the case of organic farms the profitability of production and the level of income generated are determined primarily by the subsidies. Sacco et al. (2015) and Reganold and Wachter (2016) point out that organic farming is of key importance for the realization of the idea of sustainable development, and therefore should also be supported financially, but the need to feed the population causes that other systems of agricultural production will be developed and improved as well. Zimny (2007) and Therond et al. (2017) report that the agricultural science literature employs various names, definitions and classifications of agricultural systems. They believe it is important to adopt a uniform system of such definitions and classification, as that 
will allow each of them to develop without conflict with ecological development. Regarding the subject in question, Zegar (2018) is of the opinion that in the future one should take into account a dual character of both agriculture and the food production system, as well as a progressing process of decrease of the share of population involved in agricultural production and inhabiting rural areas.

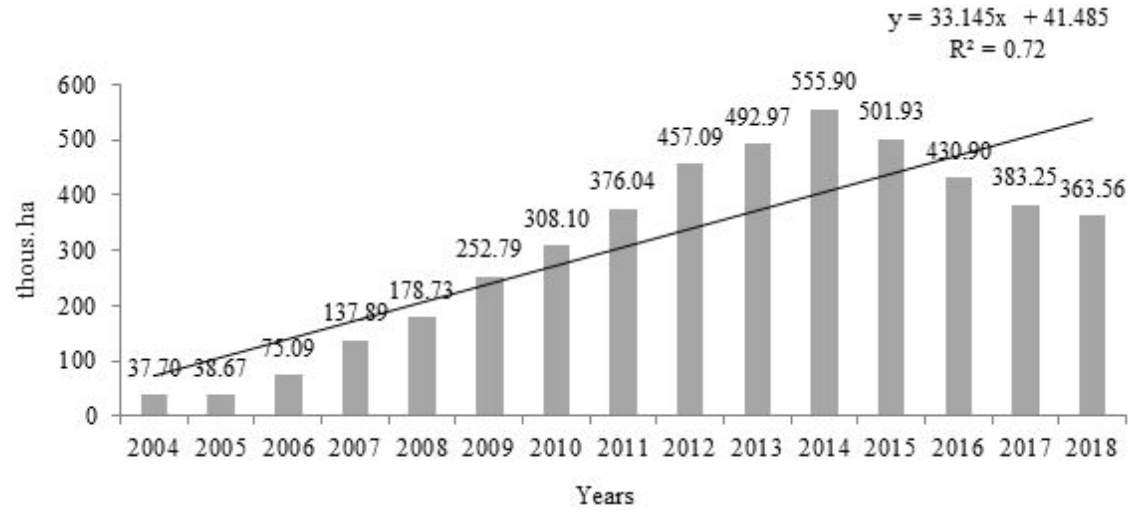

Fig. 2. Area of organic farmlands after the end of the period of conversion (Source: IJHARS).

In the analysed period, the area of organic farmlands during conversion was subject to notable variation in individual years (Fig. 3). In the years 2004-2011 interest in the conversion of farmlands to organic production increased dynamically. However, in the years 2012-2015 it began to decrease significantly. A repeat increase in the area of organic farmlands during the conversion period was noted in 2016.

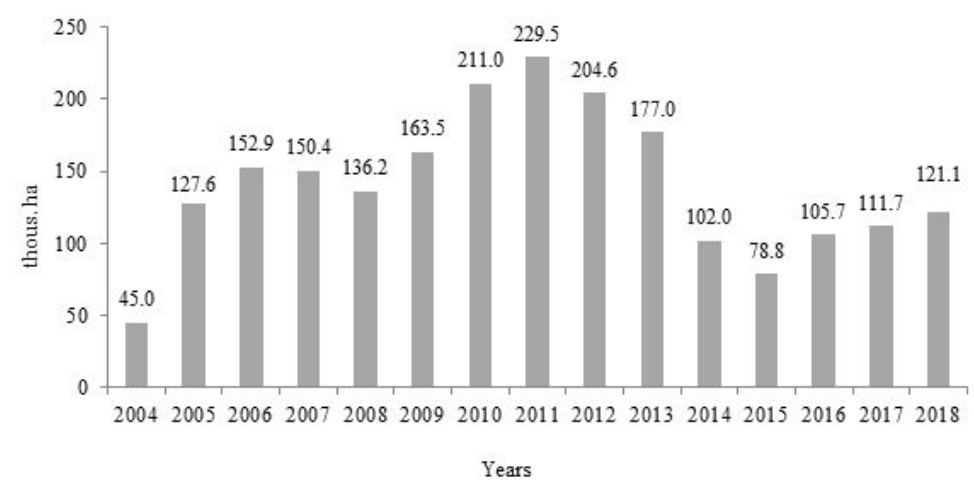

Fig. 3. Area of organic farmlands during the conversion period (Source: IJHARS).

Kuś and Jończyk (2009) observed that certain farms, being in the period of conversion to the system of organic production, were oriented at the acquisition of immediate financial benefits (subsidies), without any intention of long-term organic 
farming. Zuba-Ciszewska and Bojarszczuk (2018), on the other hand, indicate a high value and dynamics of investment at certain organic farms, which may be evidence of real intent to continue environment-friendly agricultural production.

In the period under analysis a change took place in the area structure of organic farms in Poland (Tab. 1). In the years 2005-2010, very small (up to 5 ha) or small (5$10 \mathrm{ha}$ ) farms were dominant, depending on the year. From 2011 to 2015, the largest number of farms fell within the category of 5-10 ha and 10-20 ha. In the period of 2016-2018 a high percentage was constituted by farms with areas of 10-20 ha and 20-50 ha. In this aspect it should be reminded that full subsidies were paid up to the limit of 50 ha of area under organic farming. Kuś and Jończyk (2013) report that organic farms in Poland, and also in the individual Provinces, are on average 3-fold larger compared to the total population of Polish farms. Nachtman (2015) points out that in statistical analyses one should take into account the fact that in certain cases there was concurrent organic and conventional farming production in certain farms.

Table 1. Area structure of organic farms (\%) (Source: IJHARS)

\begin{tabular}{lllcccc}
\hline \multirow{2}{*}{ Year } & \multicolumn{7}{c}{ Farm size in ha } \\
\cline { 2 - 7 } & up to 5 & $5-10$ & $10-20$ & $20-50$ & $50-100$ & above 100 \\
\hline 2004 & 19.0 & 25.0 & 26.0 & 18.0 & 7.0 & 5.0 \\
2005 & 28.0 & 26.0 & 21.0 & 14.0 & 7.0 & 4.0 \\
2006 & 26.0 & 26.0 & 21.0 & 15.0 & 8.0 & 4.0 \\
2007 & 28.0 & 25.0 & 19.0 & 15.0 & 8.0 & 5.0 \\
2008 & 36.5 & 23.5 & 18.0 & 13.0 & 6.0 & 3.0 \\
2009 & 33.6 & 22.2 & 19.3 & 14.1 & 7.2 & 3.7 \\
2010 & 23.7 & 24.3 & 22.0 & 16.5 & 9.0 & 4.5 \\
2011 & 21.1 & 24.2 & 23.8 & 17.1 & 9.2 & 4.7 \\
2012 & 19.3 & 24.1 & 25.5 & 17.4 & 9.1 & 4.6 \\
2013 & 18.8 & 23.7 & 26.3 & 17.9 & 8.9 & 4.4 \\
2014 & 14.5 & 23.3 & 28.2 & 20.3 & 9.0 & 4.7 \\
2015 & 14.3 & 22.5 & 28.5 & 21.3 & 9.0 & 4.4 \\
2016 & 20.3 & 20.4 & 26.5 & 20.8 & 8.4 & 3.6 \\
2017 & 20.1 & 19.7 & 26.1 & 21.9 & 8.7 & 3.5 \\
2018 & 21.0 & 18.1 & 25.7 & 22.6 & 8.9 & 3.7 \\
\hline
\end{tabular}

In the individual provinces the development of organic farming was varied (Fig. 4). In the years 2017 and 2018 the highest total number of organic farms was noted in the Warmińsko-mazurskie and Podlaskie Provinces. Large numbers of organic farms were also characteristic of the Mazowieckie, Zachodniopomorskie and Lubelskie Provinces. In turn, in the Opolskie and Śląskie Provinces the total numbers of organic farms were the smallest. In many publications (Kowalska 2011, Jończyk 2014, Kisiel and Grabowska 2014, Jańczak-Pieniążek et al. 2018) it was demonstrated that the status of organic farming in Poland is diversified regionally, which is most often presented in statistics on the scale of the individual provinces.

In the years 2017-2018 the largest combined area of organic farmlands was noted in the Warmińsko-mazurskie and Zachodniopomorskie Provinces. The Podlaskie Province ranked third. They smallest areas of organic farmlands were to be found in the Kujawsko-pomorskie, Łódzkie, Małopolskie, Opolskie, Śląskie and 
Świętokrzyskie Provinces (Fig. 5). Kasiczak and Głowacka (2019) confirm that the strong regional diversification of organic farming in Poland, which is best illustrated by data from the individual provinces. Pawlewicz and Pawlewicz (2008) demonstrated that first of all the regions of west and east Poland, due to favourable regional conditions, have a large percentage share of organic farmlands.

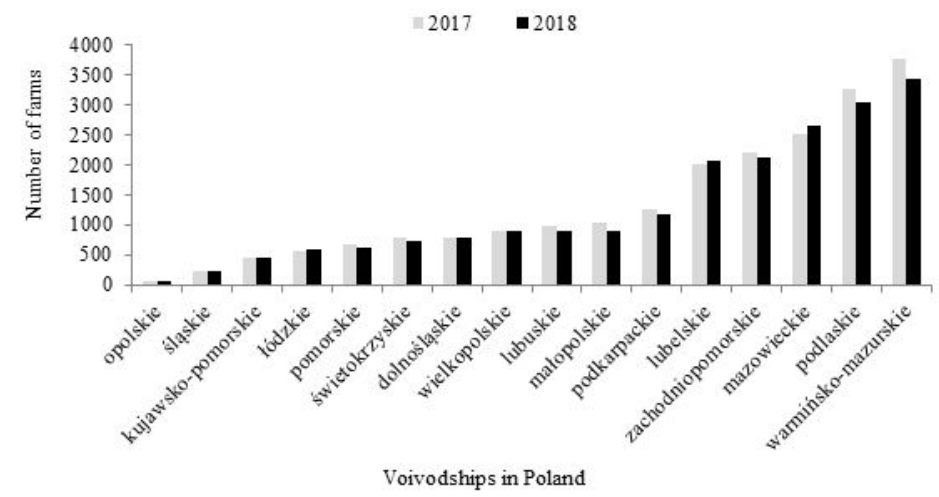

Fig. 4. Total number of organic farms in the Provinces (Source: IJHARS).

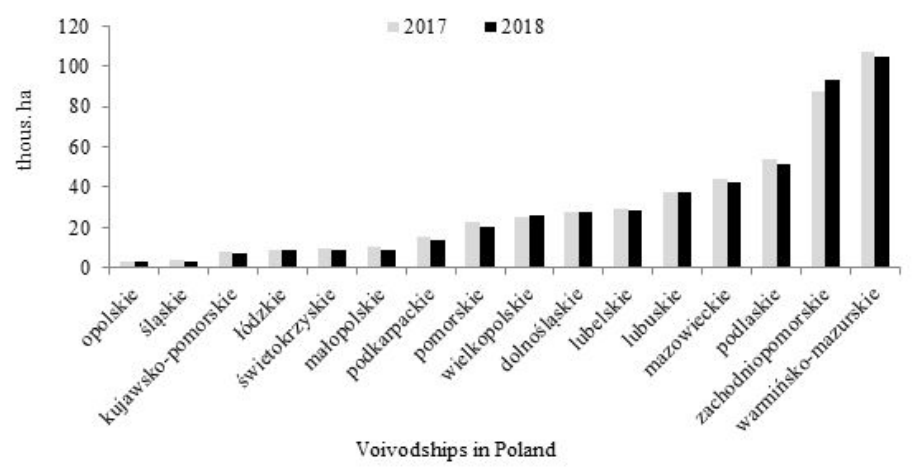

Fig. 5. Total area of organic farmlands in the Provinces (Source: IJHARS).

\section{CONCLUSIONS}

1. In the years 2004-2013 the number of organic farms in Poland increased dynamically. From 2014 the situation changed and the decreasing dynamics persisted in subsequent years. The main cause of that situation was the new rules of financial support for organic farming.

2 . The area of organic farmlands after the end of the period of conversion increased until 2014, and began to shrink starting from 2015. In turn, the area of organic farmlands in the period of conversion started to decrease over the period of 20122015, and increases again from 2016. 
3. During the period under analysis the share of small-area organic farms decreased, while that of larger farms, with areas in the range of 10-20 and 20-50 ha, increased.

4. In the years 2017 and 2018 the largest numbers of organic farms were noted in the Warmińsko-mazurskie and Podlaskie Provinces. The largest areas of organic farmlands were characteristic of the Warmińsko-mazurskie and Zachodniopomorskie Provinces.

Conflict of interest: The Authors does not declare conflict of interest.

\section{REFERENCES}

Barłowska J., Wolanciuk A., Idec J., 2017. Organic farming in Poland against the background of the European Union and the World (in Polish). Przegląd Hodowlany, 2, 1-4.

Biernat-Jarka A., Trębska P., 2018. The importance of organic farming in the context of sustainable development of rural areas in Poland. Acta Sci. Pol. Oeconomia, 17(2), 39-47, DOI: 10.22630/ ASPE.2018.17.2.19

Brodzińska K., 2010. Organic farming development in Poland in the context of environmental conditions and financial support system (in Polish). Zesz. Nauk. SGGW Warszawa, Problemy Rolnictwa Światowego, 10(2), 12-21.

Brodzińska K., 2014. Organic farming - trends and directions of changes (in Polish). Zesz. Nauk. SGGW Warszawa, Problemy Rolnictwa Światowego, 14(3), 27-36.

Brzezina N., Biely K., Helfgott A., Kopainsky B., Vervoort J., Mathijs E., 2017. Development of organic farming in Europe at the crossroads: Looking for the way forward through system archetypes lenses. Sustainability, 9(821), 1-23, https://doi.org/10.3390/su9050821

Crowder D.W., Reganold J.P., 2015. Financial competitiveness of organic agriculture on a global scale. PNAS, 112(24), 7611-7616. https://doi.org/10.1073/pnas.1423674112

Domagalska J., Buczkowska M., 2015. Organic farming - opportunities and perspectives (in Polish). Probl. Hig. Epidemiol., 96(2), 370-376.

Drabarczyk K., Wrzesińska-Kowal J., 2015. The development of organic farming in Poland (in Polish). Zesz. Nauk. SGGW Warszawa. Ekonomika i Organizacja Gospodarki Żywnościowej, 111, 19-31, https://doi.org/10.22630/EIOGZ.2015.111.31

Głodowska M., Gałązka A., 2017. Impact of organic farming on natural environment within the concept of sustainable development (in Polish). Wieś i Rolnictwo, 2(175), 147-165, https://doi. org/10.7366/wir022017/07

Hole D.G., Perkins A.J., Wilson J.D., Alexander I.H., Grice P.V., Evans A.D., 2005. Does organic farming benefit biodiversity? Biol. Conserv., 122(1), 113-130, https://doi.org/10.1016/j. biocon.2004.07.018

Jańczak-Pieniążek M., Jarecki W., Buczek J., Bobrecka-Jamro D., 2018. Development of organic agriculture in Podkarpackie voivodship against Poland background (in Polish). Fragm. Agron., 35(3), 66-76.

Jasiński J., Michalska S., Śpiewak R., 2014. Organic farming as a factor of local growth (in Polish). Wieś i Rolnictwo, 4(165), 145-158.

Jończyk K., 2014. Development of organic farming in Poland. Zesz. Nauk. WSEI seria: Ekonomia, $8(1), 129-140$.

Kasiczak A., Głowacka A., 2019. Changes in the number and area of certified organic farms in Poland after accession to the European Union (in Polish). Agronomy Science, 74(2), 25-35, https://dx. doi.org/10.24326/as.2019.2.3 
Kisiel R., Grabowska N., 2014. The role of European Union subsidies in the development of organic farming in Poland - an example of Podlasie region (in Polish). Woda - Środowisko - Obszary Wiejskie, 14(3), 61-73.

Kondratowicz-Pozorska J., 2014. Support for ecological farms in Poland in 2004-2013 and in the perspective of 2014-2020 (in Polish). Pr. Nauk. UE Wrocław, 361, 108-116. https://doi.org/10.15611/ pn.2014.361.11

Kowalska A., 2011. The organic agriculture development in Dolnośląskie province (in Polish). Rocz. Nauk. SERiA, 13(5), 39-43.

Kowalska A., 2015. Organic farming as a development factor of sustainable consumption (in Polish). J. Agribus. Rural Dev., 3(37), 467-476. DOI: 10.17306/JARD.2015.49

Krupa M., Witkowicz R., Jacyk G., 2016. Cost effectiveness of production in organic farms participating in Polish FADN (in Polish). Fragm. Agron., 33(3), 46-56.

Kuś J., Jończyk K., 2009. Development of organic farming in Poland. J. Res. Appl. Agric. Eng., 54(3), $178-182$.

Kuś J., Jończyk K., 2013. Development of organic farming in the last 20 years in Poland and UE. J. Res. Appl. Agric. Eng., 58(4), 38-43.

Ligenzowska J., 2014. Organic farming in the world (in Polish). Zesz. Nauk. SGGW Warszawa, Problemy Rolnictwa Światowego, 14(3), 150-157.

Marszałek A., 2018. Organic farming and organic food as an opportunity for sustainable development of rural areas (in Polish). Problemy Drobnych Gospodarstw Rolnych, 4, 51-68, https://dx.doi. org/10.15576/PDGR/2018.4.51

Nachtman G., 2015. Farms combining organic and conventional production methods at the background of organic farms (in Polish). Zagadnienia Ekonomiki Rolnej, 3(344), 129-147, https://doi. org/10.5604/00441600.1167241

Nowogródzka T., 2012. Current status and prospects of organic farming in Poland (in Polish). Zesz. Nauk. SGGW Warszawa, Problemy Rolnictwa Światowego, 12(2), 54-65.

Pawlewicz A., Pawlewicz K., 2008. Spatial differentiation of organic agricultural production in Poland (in Polish). Zesz. Nauk. SGGW Warszawa, Problemy Rolnictwa Światowego, 5(20), 109-115.

Reganold J.P., Wachter J.M., 2016. Organic agriculture in the twenty-first century. Nature Plants, 2, 1-8, https://doi.org/10.1038/nplants.2015.221

Sacco D., Moretti B., Monaco S., Grignani C., 2015. Six-year transition from conventional to organic farming: effects on crop production and soil quality. Europ. J. Agron., 69, 10-20. https://doi. org/10.1016/j.eja.2015.05.002

Staniak S., 2014. Characteristics of food produced in organic farming (in Polish). Polish J. Agron., $19,25-35$.

Therond O., Duru M., Roger-Estrade J., Richard G., 2017. A new analytical framework of farming system and agriculture model diversities. A review. Agron. Sustain. Dev., 37(3), 1-24, https://doi. org/10.1007/s13593-017-0429-7

Zegar J.S., 2018. Agriculture and Rural Development (in Polish). Wieś i Rolnictwo, 2(179), 31-48, https://doi.org/10.7366/wir022018/02

Zimny L., 2007. Definitions and divisions of farming systems (in Polish). Acta Agroph., 10(2), 507-518.

Zuba-Ciszewska M., Bojarszczuk J., 2018. Effectiveness of organic farms in relation to their agricultural types (in Polish). Agronomy Science, 72(4), 99-111, https://doi.org/10.24326/as.2017.4.10 